INTERNATIONAL HIGHER EDUCATION, Number 73 Fall 2013

Pages 26-27

\title{
New Missions and Ambitions for Russian Universities
}

TATIANA KASTOUÉVA-JEAN

Tatiana Kastouéva-Jean is a research fellow at the French Institute of International Relations, Paris. E-mail: jean@ifri.org.

Russian universities are facing many new challenges. On the domestic level, Russian authorities ask them not only to train highly qualified personnel for the national economy but to also become important actors in research and development and innovation. This role was traditionally played by the Russian Academy Sciences, but it has had trouble reforming itself and thus has lost legitimacy. On an international level, President Vladimir Putin wants five Russian universities in the global top 100 by 2020. In addition to economic dividends from attracting foreign students, having such leaders should improve the image of Russia as an international educational and scientific power. In spite of efforts (for example, Russia joined the Bologna process in 2003), internationalization of Russian higher education remains weak: in 2010, Russia hosted 3.9 percent of international students worldwide, the overwhelming majority coming from Commonwealth of Independent States countries (former Soviet Union). Only two Russian universities appear in Shanghai Academic Ranking of World Universities: Moscow State University in 80th level and Saint- 
Petersburg State University in the last 100th. Russia's road to international leadership seems to be a long one.

\section{Difficult StaRTing Conditions}

In the 1990s and in the beginning of 2000s, Russian universities went through a difficult period of transition and insufficient state funding. During these lean times, they had to develop strategies for survival: universities, including public establishments, offered more payment of educational services (as a result, $60 \%$ of students are enrolled today for a fee) and opened regional branches and departments teaching non-core disciplines that were in demand (especially law, economics, and management). Aging and badly paid faculty members combined positions in multiple establishments with private lessons, in order to make a living. The simultaneous growth in the social prestige of diplomas, with the democratization of higher education, encouraged the spread of corrupt practices, plagiarism, and the outright purchase of diplomas. With only a few exceptions, the quality of training deteriorated.

In addition to this challenging legacy, student demography is a worrying factor for future. Because of low birthrates in the 1990s, the number of young people between 14 and 19 years old dropped from 11 million in 2007 to 7.6 million in 2012. In a short and medium term, this demographic situation is a challenge for universities. Closures, reorganizations, and mergers will obviously be necessary to manage surplus capacity in higher education. These processes are already underway: between 2008 and 2012, 88 establishments disappeared and the number of student population shrank by 1,460,000. Clearly, competition between universities for candidates will be hard in the coming years. 


\section{Things Change...}

Since 2005, the government has sought to reverse the negative trends in the sector and to modernize the education system. State funding for higher education increased from 119 billion rubles in 2005 ( $\$ 4$ billion) to 402.4 billion in 2011 (\$13 billion). In October 2012, Prime Minister Dmitry Medvedev promised that spending on education will be equal to the defense budget by 2020. It is the first time in Russian history that education and defense have been given the same level of priority. However, the average spend per student remains extremely low even in leading universities $(\$ 8,000$ versus $\$ 14,000$ on average in the Organization for Economic Cooperation and Development countries or $\$ 30,000$ on average in the United States).

Three Excellence Initiatives were launched in order to select the most promising universities. The new quality-labels "National research universities" and "Federal universities" (created by mergers in regions) were created, representing 5 percent of all Russian universities. These received significant additional funding and some now have modern equipment and laboratories that would make even Western universities green with envy. Various measures were undertaken in order to integrate teaching and research, to bring universities closer to companies, and to encourage them to create startups and business incubators. The Russian government is clearly inspired by the Massachusetts Institute of Technology and the Stanford University model. 


\section{...But Not ENOUgh?}

Some factors have been overlooked. Thus, the success of reforms has been put at risk. First, the human capital of teaching and research professions needs to be reconsidered. This will require an appropriate salary—at present that remains a promise for the majority of universities-and an increase of social prestige in order to attract the mostly highly talented professors. This should replace recruitment by cooptation; in some universities, 90 percent of teachers are recruited from among former students. Courses prepared in a "copy and paste" manner, compartmentalization between disciplines, and old methods of teaching should be changed. The scientific reputation of each researcher should be as important as an appropriate salary. Recently, a long series of recent scandals over plagiarized dissertations demonstrated not only the degree of corruption in the higher education system but, as well, the overall weak level of research in Russia. The barriers between research and teaching should be abolished: for instance, teachers have a different status and salary to researchers and the number of teaching hours is three or four times more than in Western countries.

This traditional separation between teaching and research is a second core handicap to the achievement of the new national and international missions for universities. In 2010, universities accounted for only 15 percent of all national research organisms, employed 6.4 percent of personnel in research and development nationally, while their share of domestic expenditure on research and development represented 8.4 percent. The average figure of the Organization for Economic Cooperation and Development countries is at the same moment being 26.6 percent. It is clear that universities have progress to make. 
Third, the state seeks to establish the ideal model in a short line. Such a mechanistic approach does not take into account numerous obstacles: the duration of natural processes, relations with a number of socioeconomic factors, the interests of the parties, the inertia of the system, and institutional resistance. This could encourage a mechanical and superficial implementation of quantitative indicators of development programs in order to satisfy the ministry and thus preserve the volume of state funding. For example, the number of startups created can be impressive, but their turnover is often weak, their products are not competitive, and their viability in real economic conditions is questionable.

Fourth, despite the newly created status of autonomous establishments, even leading Russian universities remain impeded with the dominant role and overwhelming control exercised by the ministry, which decides everything from the number of "budget" (free) places for students by region and by specialization to wages and utilization of funding. At a time when ambitious development programs are not accompanied by appropriate implementation mechanisms, there is a risk that in the short to medium term the reform of Russian education will get stuck. Considering tough international competition, Russian universities risk being ousted to the periphery of the global educational space permanently. 